\title{
Rola komentatora liturgicznego w ramach posługi słowa i jego formacja biblijna
}

\author{
Beata Stypułkowska \\ Wyższy Instytut Teologiczny w Częstochowie \\ stypulkowska.czest@gmail.com (D) https://orcid.org/0000-0002-8978-7190
}

W niniejszym artykule zostanie przeprowadzona refleksja nad rolą komentatora liturgicznego w ramach posługi słowa, na którą będą składały się kwestie związane z udziałem osób świeckich w posłudze słowa i pomocniczą rolą świeckich w liturgii słowa (1), homilią i komentarzem liturgicznym przed czytaniami (2) oraz biblijną formacją komentatorów (3).

Wojciech Kosmowski komentatorem liturgicznym nazywa osobę, która czyta komentarz, a nie tę, która go przygotowuje ${ }^{1}$. Ponieważ jednak nie zaproponowano nazwy dla osoby, która pisze komentarz, w niniejszym artykule zarówno ten, kto odczytuje komentarz, jak i ten, kto go przygotowuje zostali określeni jednym terminem „komentator liturgiczny”. Tak zdaje się sugerować ks. Franciszek Blachnicki, który wśród zadań komentatora wymienia przygotowanie tekstu komentarza i uczestnictwa wiernych we mszy świętej, co obejmuje dobór pieśni i tekstów do recytacji, przygotowanie tekstów, uzgodnienie programu z organistą, przygotowanie lektora, ministrantów i scholi² .

1 W. Kosmowski, Komentator liturgiczny i jego posługa, Bydgoszcz 1997, s. 20. Jednakże w Leksykonie liturgii nie ma takiego zastrzeżenia - por. Komentator (komentarz), [w:] Leksykon liturgii, oprac. B. Nadolski, Poznań 2006, s. 656.

2 F. Blachnicki, H. Boliński, Komentator i komentarz w zgromadzeniu liturgicznym, 1967 (mps), s. 27-28. 
Niniejszy artykuł jest związany z wcześniejszą publikacją na temat lektorów dorosłych ${ }^{3}$, w której skoncentrowano się na formacji. Zarówno formacja lektora, jak i formacja komentatora do czytań mają wiele wspólnego i w zasadniczej części mogą być prowadzone razem. Dlatego też w odniesieniu do komentatora liturgicznego aktualne są propozycje podane we wspomnianym artykule i w niniejszym tekście nie będą one powtarzane. Przygotowanie komentatora, który układa komentarz liturgiczny do czytań, musi być jednak szersze niż przygotowanie lektora, dlatego też poświęcono tej sprawie oddzielną uwagę.

\section{1. Świeccy w posłudze słowa}

Kodeks Prawa Kanonicznego stanowi o tym, że wierni świeccy w wykonywaniu posługi słowa mogą być powoływani na współpracowników biskupów i prezbiterów ${ }^{4}$. Pojawiają się pytania o charakter tej współpracy.

W Leksykonie teologii pastoralnej przy omawianiu apostolstwa świeckich ks. Wiesław Przygoda mówi o apostolstwie własnym oraz apostolstwie pomocniczym katolików świeckich. To pierwsze odnosi się do odnowy porządku doczesnego, a to drugie związane jest w szczególny sposób z hierarchią. Apostolstwo pomocnicze podzielone zostało na zwyczajne i nadzwyczajne. Przez apostolstwo pomocnicze zwyczajne należy rozumieć działanie oparte na mandacie apostolskim, który łączy to apostolstwo z apostolstwem hierarchii. Mandat apostolski polega na specjalnym poparciu i przyjęciu odpowiedzialności za dzieło apostolskie, dzięki któremu działalność osoby lub zespołu osób świeckich nabiera cech apostolstwa urzędowego. Oprócz mandatu istnieją różne stopnie aprobaty hierarchii dla apostolstwa świeckich: zatwierdzenie statutu organizacji, wyznaczenie asystenta kościelnego, przyjęcie do wiadomości istnienia organizacji, pochwała jej celów. Apostolstwo

3 B. Stypułkowska, Przygotowanie dorosłych do posługi lektora w ramach katechezy biblijnej, [w:] Teologiczne refleksje wokół tajemnicy wiary, red. R. Ceglarek, P. Maciaszek, Częstochowa 2020, s. 105-116.

4 Kodeks prawa kanonicznego. Przekład polski zatwierdzony przez Konferencję Episkopatu, Poznań 1984, kan. 759. 
pomocnicze nadzwyczajne opiera się na misji kanonicznej i polega na uczestnictwie świeckich w niektórych czynnościach właściwych hierarchii, np. głoszeniu nauki chrześcijańskiej, pełnieniu czynności liturgicznych i opiece duszpasterskiej. Przez misję kanoniczną hierarchia udziela świeckim uprawnień, których na podstawie chrztu i bierzmowania nie posiadają ${ }^{5}$.

Przytoczone hasło słownikowe budzi zastrzeżenia. Misję kanoniczną otrzymują również prezbiterzy, gdy kierowani są do pracy w szkole, a którzy przecież posiadają sakrament święceń. Zatem misja kanoniczna nie jest związana tylko z udzieleniem uprawnień świeckim, których nie mają na podstawie chrztu i bierzmowania. Poza tym głoszenie nauki chrześcijańskiej jest określeniem szerokim, które obejmuje również chrześcijańskie wychowanie swoich dzieci przez rodziców i wprowadzanie ich w zrozumienie prawd wiary, co jest podstawowym obowiązkiem rodziców, do którego nie otrzymują misji kanonicznej. Określenie „apostolstwo pomocnicze” jest niezbyt fortunnym sformułowaniem. Już Pius XI w encyklice o Akcji Katolickiej mówił o współudziale i współpracy laikatu przy apostolacie hierarchicznym, nie nazywając tego apostolstwem pomocniczym ${ }^{6}$. Określenie „apostolstwo pomocnicze” sugeruje rolę podrzędną prowadzonej działalności i kojarzy się z klerykalizmem. Wprawdzie dla osób wyświęconych głoszenie słowa Bożego jest podstawowym obowiązkiem, ale wielu wiernych świeckich odczytuje wezwanie do posługi słowa, która nie musi być związana z sakramentem święceń. Sakrament święceń jest potrzebny do proklamowania Ewangelii podczas liturgii oraz głoszenia homilii. Inne formy posługi słowa, takie jak ewangelizacja, katecheza, nauki rekolekcyjne, wykłady z teologii, nauka religii w szkole mogą być spełnianie zarówno przez wyświęconych, jak i wiernych świeckich. Rozróżnienie na apostolstwo hierarchiczne i apostolstwo pomocnicze świeckich w opinii niektórych pastoralistów uważane jest za naukę przedsoborową.

5 W. Przygoda, Apostolstwo świeckich, [w:] Leksykon teologii pastoralnej, red. R. Kamiński, W. Przygoda, M. Fiałkowski, Lublin 2006, s. 72-73.

6 Pius XI, Encyklika o Akcji Katolickiej Non abbiamo bisogno (29 czerwca 1931), 2. 
Jedynie w odniesieniu do liturgii słowa można mówić o pomocniczej roli świeckich w posłudze słowa. Przejawia się ona w posłudze lektora i komentatora liturgicznego, którzy należą do zespołu liturgicznego. Celem takiego zespołu jest wspieranie duszpasterzy w organizacji liturgii i nabożeństw, w doborze śpiewów oraz w określaniu tematu i treści homilii uwzględniającej potrzeby wspólnoty ${ }^{7}$. Komentator pełni funkcję liturgiczną wykonywaną na mocy zlecenia ${ }^{8}$. Do komentatora należą starannie przygotowane, zwięzłe i jasne objaśnienia i pouczenia wprowadzające wiernych w liturgię i lepsze jej rozumienie. W przypadku komentarza do czytań biblijnych chodzi o starannie przygotowane krótkie słowo przed czytaniami, które będzie zwracało uwagę na kerygmat i przygotowywało do homilii. Komentator jest bowiem współpracownikiem prezbitera w przygotowaniu homilii, a bez związku homilii z komentarzem nie może być mowy o dobrym komentarzu liturgicznym. Jednakże komentarz nigdy nie będzie słowem Bożym, którym jest homilia. Komentator zachęca do słuchania, natomiast kaznodzieja w czasie liturgii jest sakramentalnym uobecnieniem Chrystusa, Głowy i Pasterza, który przemawia ${ }^{9}$.

\section{Homilia i komentarz liturgiczny przed czytaniami}

Homilia jest częścią liturgii Kościoła, dlatego może być głoszona wyłącznie przez biskupów, prezbiterów lub diakonów, czyli tych, którzy są wyświęceni do przewodniczenia lub asystowania przy ołtarzu ${ }^{10}$ i mają

7 II Polski Synod Plenarny (1991-1999), Poznań 2001, s. 204, 83.

8 Ogólne wprowadzenie do Mszału rzymskiego. Z trzeciego wydania Mszału Rzymskiego. Rzym 2002, Poznań 2004, 105; C. Krakowiak, Posługi i funkcje świeckich w liturgii w świetle nowego Ogólnego Wprowadzenia do Mszału Rzymskiego i instrukcji Redemptionis sacramentum, [w:] Liturgia i ewangelizacja. Materiały z Pierwszego Sympozjum Liturgicznego Diecezji Siedleckiej, Siedlce, 16 października 2004 r., red. W. Kazimieruk, I. Chłopkowska, Warszawa-Siedlce 2005, s. 37-38.

9 Kongregacja ds. Duchowieństwa, Instrukcja Kapłan, pasterz i przewodnik wspólnoty parafialnej (4 sierpnia 2002), 20.

10 Kongregacja Kultu Bożego i Dyscypliny Sakramentów Instrukcja o tym, co należy zachowywać, a czego unikać w związku z Najświętszą Eucharystią Redemptionis sacramen- 
prawo podczas liturgii czytać Ewangelię. Komentarz liturgiczny może być wygłoszony lub odczytany przez celebransa lub wiernego świeckiego. Homilia winna być wyjaśnieniem jakiegoś aspektu czytań Pisma Świętego albo innego tekstu spośród stałych lub zmiennych części mszy danego dnia, z uwzględnieniem zarówno obchodzonego misterium, jak i szczególnych potrzeb słuchaczy ${ }^{11}$. W sytuacji, gdy homilia odnosiłaby się do tekstu liturgicznego spośród stałych lub zmiennych części mszy świętej, wówczas komentarz liturgiczny przed czytaniami winien stanowić ogólną zachętę do uważnego uczestniczenia w liturgii słowa. Jednakże najbardziej pożądana jest sytuacja, gdy głoszone słowo Boże na podstawie tekstu z Pisma Świętego i modlitw liturgicznych wraz z liturgią eucharystyczną staje się przepowiadaniem przedziwnych dzieł Bożych w historii zbawienia, czyli misterium Chrystusa ${ }^{12}$. Modlitwy liturgiczne niosą bowiem hermeneutykę przydatną do interpretacji tekstów biblijnych przez kaznodzieję ${ }^{13}$.

Dyrektorium homiletyczne podaje trzy etapy homilii. Pierwszy z nich dotyczy paschalnego misterium Chrystusa, które jest głoszone w czytaniach i homilii. Kaznodzieja winien mówić o czytaniach i modlitwach $\mathrm{z}$ celebracji w taki sposób, że zostanie ukazane ich znaczenie przez pryzmat śmierci i zmartwychwstania Chrystusa ${ }^{14}$. Wprowadzeniem do tego etapu winien być komentarz liturgiczny. Komentarz z jednej strony ma pomóc uczestnikom liturgii w wytworzeniu wewnętrznej dyspozycji do spotkania z Chrystusem przychodzącym w słowie; ma kierować uwagę i czujność na proklamację słowa Bożego ${ }^{15}$. Z drugiej strony wydaje się, że komentarz powinien sygnalizować kerygmat, który będzie głoszony w ramach homilii. Kerygmat jest orędziem o faktach i czynach, przez które Bóg wkroczył w historię ludzkości, powołując ją do wejścia w Jego zbawcze plany. Kerygmat apostolski

tum (25 marca 2004), 161.

11 Ogólne wprowadzenie do Mszału rzymskiego, 65.

12 Sobór Watykański II, Konstytucja o liturgii Sacrosanctum Concilium, 35; Wprowadzenie do drugiego wydania Lekcjonarza mszalnego z 1981 roku, 24, [w:] Lekcjonarz mszalny, t. 1: Okres Adwentu, okres Narodzenia Pańskiego, wyd. 2, Poznań 2015, s. 11-55.

13 Wprowadzenie do drugiego wydania Lekcjonarza mszalnego z 1981 roku, 24.

14 Kongregacja Kultu Bożego i Dyscypliny Sakramentów, Dyrektorium homiletyczne, 12.

15 W. Kosmowski, Komentator liturgiczny i jego posługa, dz. cyt., s. 23. 
jest odzwierciedleniem kerygmatu Jezusa, rozumianego i interpretowanego w świetle Jego śmierci i zmartwychwstania ${ }^{16}$. Wymaganie nawrócenia wypływa z tego, że treścią kerygmatu jest fakt zbawienia ${ }^{17}$, który dokonał się w misterium paschalnym ${ }^{18}$. Zwycięstwo Chrystusa nad śmiercią sprawia, że teraźniejszość słuchaczy kerygmatu nabiera wymiarów wieczności, a wszelkie nauczanie powinno odnosić się do dzieła zbawienia ${ }^{19}$. W głoszeniu kerygmatu nie chodzi o wyjaśnienie pewnych pojęć i zasad, lecz o przekazanie Bożego wezwania i zaproszenia $^{20}$. Karl Rahner, reprezentant odnowy kerygmatycznej, uściślił, że kerygmat we współczesnym użyciu tego nowotestamentowego terminu oznacza słowo, które w imię Boga i na mocy prawowitej misji zleconej przez Boga i Kościół jest głoszone zarówno wspólnocie wierzących, jak i jednostce jako słowo samego Boga i które skutecznie uobecnia to, co właśnie jest przepowiadane. Ponieważ jest ono historycznie uchwytnym wydarzeniem tego, co przepowiadane, dlatego jest czymś więcej i czymś innym niż wypowiedzi dogmatyczne Kościoła oraz czymś innym niż wypowiedzi będące rezultatem ludzkiej refleksji nad dogmatami (teologią). Najintensywniejsze swe wypełnienie kerygmat znajduje w sakramencie jako manifestacji zbawienia Bożego ${ }^{21}$.

Wskazuje na to drugi etap homilii, który według Dyrektorium homiletycznego przygotowuje wspólnotę do celebrowania Eucharystii i łączy paschalne misterium Chrystusa z ofiarą mszy świętej ${ }^{22}$. Natomiast trzeci etap homilii ma podpowiadać na podstawie czytań biblijnych, jak członkowie wspólnoty, przemienieni przez Eucharystię, mogą w swoim

16 A. Paciorek, Kerygmat, [w:] Encyklopedia katolicka, t. 8, Lublin 2000, k. 1361.

17 J. Audusseau, X. Léon-Dufour, Głosić, [w:] Stownik teologii biblijnej, red. X. Léon-Dufour, tłum. i oprac. K. Romaniuk, Poznań-Warszawa 1973, s. 278.

18 J. Audusseau, X. Léon-Dufour, Głosić, art. cyt., s. 279.

19 J. Audusseau, X. Léon-Dufour, Głosić, art. cyt., s. 279; A. Barucq, P. Grelot, Nauczać, [w:] Stownik teologii biblijnej, dz. cyt., s. 532.

20 F. Blachnicki, Kerygmatyczna odnowa katechezy (zorientowanie w problematyce), Warszawa 2005, s. 179.

21 Kerygmat, [w:] K. Rahner, H. Vorgrilmer, Mały stownik teologiczny, tłum. T. Mieszkowski, P. Pachciarek, słowo wstępne A. Skowronek, Warszawa 1987, k. 175.

22 Kongregacja Kultu Bożego i Dyscypliny Sakramentów, Dyrektorium homiletyczne, 13. 
powszednim życiu nieść Ewangelię w świat ${ }^{23}$. Komentarz liturgiczny przed czytaniami związany organicznie z etapem pierwszym homilii może już nie odnosić się do drugiego i trzeciego etapu. Należy pamiętać, że komentarz ma być krótki i nie powinien zastępować homilii. Komentator będzie brał pod uwagę kontekst liturgiczny, który jest kluczem do interpretacji tekstów biblijnych proklamowanych w trakcie celebracji ${ }^{24}$, ale nie będzie streszczał homilii.

\section{Formacja biblijna komentatorów liturgicznych}

Niektórzy uważają, że funkcja komentatora jest równorzędna i paralelna w zgromadzeniu liturgicznym do funkcji lektora oraz - powołując się na ks. Franciszka Blachnickiego - że powinno się zachować podział funkcji między chłopcami lub mężczyznami (lektorzy) a dziewczętami lub kobietami (komentatorki) ${ }^{25}$. Zrównanie posługi lektora z posługą komentatora wydaje się niewłaściwe. Lektor czyta słowo Boże, które jest integralną częścią liturgii, komentator zaś czyta komentarz do tego słowa, który jest niekonieczny. Gdy w Kościele czyta się Pismo Święte, wówczas sam Bóg przemawia ${ }^{26}$, gdy czytany jest komentarz, czytane jest ludzkie słowo. Dlatego kryterium wyznaczenia kogoś do posługi lektora czy komentatora nie powinna być płeć danej osoby, lecz umiejętność czytania ze zrozumieniem i dobra dykcja, tak by słuchający mieli z tego pożytek i by słowo Boże było przeczytane w godziwy sposób ${ }^{27}$.

Wprowadzenie do lekcjonarza mszalnego wskazuje na dwa rodzaje przygotowania do posługi lektora: przygotowanie duchowe i techniczne. Duchowe przygotowanie zakłada formację biblijną i liturgiczną.

23 Tamże, 14.

24 Tamże, 15.

25 W. Kosmowski, Komentator liturgiczny i jego posługa, dz. cyt., s. 21; F. Blachnicki, Funkcje dziewcząt w zgromadzeniu liturgicznym jako punkt wyjścia pracy wychowawczej, „Collectanea Theologica” 45 (1975) nr 3, s. 63.

26 Sobór Watykański II, Konstytucja o liturgii Sacrosanctum Concilium, 35; Ogólne wprowadzenie do Mszału rzymskiego, 29.

27 Benedykt XVI, Adhortacja apostolska o słowie Bożym w życiu i misji Kościoła Verbum Domini, 16. 
Przygotowanie techniczne dotyczy publicznego czytania tekstu, również przy pomocy współczesnych urządzeń nagłaśniających ${ }^{28}$. Biblijna formacja lektorów zmierza do tego, aby lektor rozumiał czytania w ich własnym kontekście oraz w świetle wiary pojmował istotną treść objawienia. Formacja liturgiczna natomiast winna zapewnić lektorowi znajomość sensu struktury liturgii słowa i jej związku z liturgią eucharystyczną ${ }^{29}$. Poza tym w ramach formacji liturgicznej lektor winien zapoznać się z lekcjonarzami mszalnymi, kalendarzami liturgicznymi, cyklami czytań mszalnych itp. ${ }^{30}$ oraz przejść szkolenie praktyczne polegające na ćwiczeniach z emisji głosu oraz czytaniu z ambony i przez mikrofon perykop biblijnych przeznaczonych dla lektora. Wydaje się, że wierny, zanim zacznie podczas liturgii czytać słowo Boże, powinien najpierw odczytywać komentarze lub wezwania modlitwy wiernych. Gdy będzie dobrze spełniał te czynności, wówczas może podjąć posługę lektora. Rubryki w lekcjonarzu podają podtytuł czytania, a tym samym jego główną myśl, co może być cenną wskazówką przy wybraniu zdania do wyakcentowania przez lektora oraz przygotowaniu komentarza. Doświadczony lektor może zostać komentatorem przygotowującym komentarze liturgiczne przed czytaniami, gdyż jest on zarówno współpracownikiem kaznodziei, jak i liderem lektorów, a komentarz winien być przygotowywany nie tylko w porozumieniu z kaznodzieją, ale i we współpracy z lektorami. Jeżeli świecki komentator w przyszłości przyjmie sakrament święceń i zostanie głosicielem słowa Bożego, doświadczenie zdobyte podczas przygotowywania komentarzy liturgicznych będzie dla niego przydatne w pracy nad homiliami.

Podczas formacji biblijnej komentatora warto wprowadzić go w praktykę lectio divina ${ }^{31}$, która jest wskazywana jako pomocna w przygo-

28 Wprowadzenie do drugiego wydania Lekcjonarza mszalnego z 1981 roku, 55.

29 Tamże, 55.

30 Opis lekcjonarza można znaleźć we Wprowadzeniu do drugiego wydania Lekcjonarza mszalnego z 1981 roku, 92-110. Na temat struktury czytań mszalnych zob. W. Świerzawski, Eucharystia Chrystusa i Kościoła, Kraków 1983, s. 40-42; J. Janicki, Obrzędy liturgii Mszy świętej, [w:] Msza święta, red. W. Świerzawski, współred. J. Boguniowski, S. Koperek, Kraków 1992, s. 231-235.

31 B. Secondin, Modlitewna lektura Pisma Świętego, t. 1: Zasady, przykłady i metoda medytacji lectio divina $w$ grupie i dla osób indywidualnych, przekł. A. Ryndak-Laciuga, Kraków 
towywaniu homilii ${ }^{32}$. Metodę tę zalecał Benedykt XVI jako najlepiej służącą spotkaniu z Chrystusem, żywym Słowem Bożym³ ${ }^{33}$. Mówi o niej również Franciszek w kontekście przygotowywania się do przepowiadania $^{34}$. Benedykt XVI opisał jej podstawowe cztery etapy: lectio, meditatio, oratio i contemplatio oraz wspomniał o uzupełniającym actio, który sprawia, że życie wierzącego staje się darem dla innych w działaniu ${ }^{35}$. Praktykę lectio divina można dostosować do swoich warunków życia. Poszczególne etapy można rozłożyć na cały dzień, można też praktykować tylko dwa pierwsze z nich, bo warto wiedzieć, że św. Benedykt nie określił żadnych etapów, nazywając po prostu tę modlitwę Bożym czytaniem. Przy lectio divina należy podjąć wysiłek poprawnego zrozumienia tekstu biblijnego. Można do tego zastosować zasady katechetycznej interpretacji Pisma Świętego ${ }^{36}$ lub też ograniczyć się do zasad podanych w Dyrektorium homiletycznym, służących interpretacji słowa Bożego w liturgii ${ }^{37}$. Oba ujęcia podają wytyczne soborowe, którymi są: treść i jedność całego Pisma Świętego, czytanie Pisma Świętego w żywej Tradycji całego Kościoła oraz uwzględnianie analogii wiary. Homilista, ale i komentator, którzy są wrażliwi na analogię wiary, starają się interpretować słowo Boże w ramach żywej Tradycji Kościoła i w świetle jedności całego Pisma Świętego, mają

2006; B. Secondin, Modlitewna lektura Pisma Świętego, t. 2: 27 przykładów, aby nauczyć się medytacji Lectio divina, przekł. A. Ryndak-Laciuga, Kraków 2006; „Uważajcie jak słuchacie” ( $Ł k$ 8, 18). Teoria i praktyka lectio divina, red. H. Witczyk, S. Haręzga, Kielce 2004; M. Masini, Wprowadzenie do lectio divina. Teologia, metoda, duchowość, praktyka, tłum. B. Żurowska, Kraków 2001; J. Kochel, W szkole słowa Bożego. Medytacje w rytmie lectio divina, Opole 2001; J. Kudasiewicz, Modlitwa Biblia. Wprowadzenie do lectio divina, Kielce 2000; K. Wons, Jak żyć słowem Bożym na co dzień, Kraków 2000; W. Zatorski, Usłyszeć stowo Boże. Praktyka „lectio divina”, Kraków 1999; E. Bianchi, Przemodlić słowo. Wprowadzenie do „lectio divina”, tłum. A. Tronina, Kraków-Tyniec 1998.

32 Kongregacja Kultu Bożego i Dyscypliny Sakramentów, Dyrektorium homiletyczne, 26-36.

33 Benedykt XVI, Adhortacja apostolska o słowie Bożym w życiu i misji Kościoła Verbum Domini, 87.

34 Franciszek, Adhortacja apostolska o głoszeniu Ewangelii w dzisiejszym świecie Evangelium gaudium, 152.

35 Benedykt XVI, Adhortacja apostolska o słowie Bożym w życiu i misji Kościoła Verbum Domini, 87.

36 B. Stypułkowska, Biblijna formacja katechetów, Częstochowa 2015, s. 279-314.

37 Kongregacja Kultu Bożego i Dyscypliny Sakramentów, Dyrektorium homiletyczne, 16-25. 
nieocenioną pomoc w postaci Katechizmu Kościoła katolickiego, który dostarcza wielu przykładów stosowania soborowych zasad interpretacyjnych. Dyrektorium homiletyczne oprócz przytoczonych zasad zwraca uwagę na to, że tajemnica paschalna, której skutecznie doświadczamy w celebracji eucharystycznej, nie tylko oświetla proklamowane Pismo Święte, lecz także przemienia życie słuchaczy ${ }^{38}$. Gdy chodzi natomiast o zrozumienie fragmentów biblijnych, podkreślony został sens duchowy Pisma Świętego, którego wielkimi mistrzami są Ojcowie Kościoła ${ }^{39}$.

Komentator w odróżnieniu od lektora medytuje nad wszystkimi tekstami biblijnymi, które występują w liturgii po to, by wydobyć z nich wspólną myśl. Powinien też we współpracy z kaznodzieją sformułować kerygmat, który będzie ukazany w liturgii słowa. Jego formacja biblijna zatem nie może ograniczać się jedynie do czytań lektorskich, ale musi uwzględniać całość liturgii. Komentator oprócz Pisma Świętego winien znać dobrze Katechizm Kościoła katolickiego oraz komentarze ojców Kościoła ${ }^{40}$. Komentator jest mistagogiem wprowadzającym w tajemni$\mathrm{cę}^{41}$, natomiast lektor użycza swojego głosu Bogu przemawiającemu podczas liturgii.

Ze względu na swoją rolę w zespole liturgicznym komentator powinien również poznać katechetyczne metody biblijne służące do pracy w małych grupach, gdyż do niego najczęściej będzie należało prowadzenie spotkań przygotowujących liturgię niedzielną. Zatem jego formacja winna uwzględniać również zdobywanie umiejętności praktycznych z zakresu dydaktyki katechezy.

38 Kongregacja Kultu Bożego i Dyscypliny Sakramentów, Dyrektorium homiletyczne, 22.

39 Tamże, 24-25.

40 Nieocenioną pomocą są komentarze ojców Kościoła do czytań liturgicznych wydane przez ks. prof. Marka Starowieyskiego: Karmię was tym, czym sam żyję. Ojcowie Kościoła komentują niedzielne czytania biblijne, oprac. M. Starowieyski, rok A, B, C, Kraków 2013-2015; Karmię was tym, czym sam żyję. Ojcowie Kościoła prowadza przez święta roku kościelnego, oprac. M. Starowieyski, Kraków 2015.

41 W. Kosmowski, Komentator liturgiczny i jego postuga, dz. cyt., s. 22. 


\section{Podsumowanie}

Rola komentatora liturgicznego przygotowującego komentarze przed czytaniami jest ważna i odpowiedzialna, a zarazem pomocnicza wobec głoszącego homilię i wręcz niekonieczna. Może się zdarzyć, że komentator świecki będzie kompetentny, biegły w naukach kościelnych i biblistyce na równi z kaznodzieją, a nawet będzie go przewyższać. Dlatego też dobro wspólnoty wymaga, by kapłan był gotowy przyjąć pomoc ze strony świeckiego komentatora i z nim współpracować. Należy przy tym pamiętać, że posługa wiernego świeckiego w liturgii słowa będzie miała zawsze charakter pomocniczy.

\section{Abstrakt}

\section{Rola komentatora liturgicznego w ramach posługi słowa i jego formacja biblijna}

W niniejszym artykule została przeprowadzona refleksja nad rolą komentatora liturgicznego w ramach posługi słowa, na którą składały się kwestie związane z udziałem osób świeckich w posłudze słowa i pomocniczą rolą świeckich w liturgii słowa (1), homilią i komentarzem liturgicznym przed czytaniami (2) oraz formacją biblijną komentatorów (3). Została ukazana pomocnicza rola komentatora liturgicznego przygotowującego komentarz przed czytaniami wobec kaznodziei głoszącego podczas liturgii homilię, która jest przepowiadaniem misterium Chrystusa. Zwrócono uwagę na kerygmat, który powinien być zasygnalizowany przez komentarz i obwieszczony przez homilię. W formacji biblijnej komentatorów zaproponowano lectio divina jako metodę przygotowującą do interpretacji słowa Bożego w liturgii.

Słowa kluczowe: komentator liturgiczny, posługa słowa, formacja biblijna

\section{Abstract}

\section{The role of the liturgical commentators in the ministry of the word and their biblical formation}

The paper presents a reflection on the role of the liturgical commentator in the ministry of word, comprising the issues related to the participation of lay persons 
in the ministry of the word and their auxiliary role in the ministry of word (1), to the homily and the introductory comment before the readings (2), and to the biblical formation of commentators (3). An auxiliary role of liturgical commentator who prepares the commentary to be read before the biblical readings in contrast to the homilist who delivers a homily which is a proclamation of the mystery of Christ was shown. The attention was paid to the kerygma, which should be signalled in the commentary and proclaimed during the homily. Lectio divina was proposed as the method of biblical formation which would prepare the commentators to the interpretation of the word of God for the liturgical purposes.

Keywords: liturgical commentator, ministry of word, biblical formation

\section{References}

Audusseau, J., \& Léon-Dufour, X. (1973). Głosić. In X. Léon-Dufour (Ed.), \& K. Romaniuk (Trans.), Stownik teologii biblijnej (p. 279). Pallottinum.

Barucq, A., \& Grelot, P. (1973). Nauczać. In X. Léon-Dufour (Ed.), \& K. Romaniuk (Trans.), Stownik teologii biblijnej (p. 532). Pallottinum.

Benedykt XVI. (2010). Verbum Domini.

Bianchi, E. (1998). Przemodlić stowo. Wprowadzenie w „lectio divina” (A. Tronina, Trans.). Tyniec - Wydawnictwo Benedyktynów.

Blachnicki, F. (1975). Funkcje dziewcząt w zgromadzeniu liturgicznym jako punkt wyjścia pracy wychowawczej. Collectanea Theologica, 45(3), 61-65.

Blachnicki, F. (2005). Kerygmatyczna odnowa katechezy. Zorientowanie w problematyce. Wydawnictwo Salezjańskie.

Blachnicki, F., \& Boliński, H. (1967). Komentator i komentarz w zgromadzeniu liturgicznym. Franciszek. (2013). Evangelium gaudium.

II Polski Synod Plenarny (1991-1999). (2001). Pallottinum.

Janicki, J. (1992). Obrzędy liturgii Mszy świętej. In W. Świerzawski, J. Boguniowski, \& S. Koperek (Eds.), Msza święta (pp. 231-235). Polskie Towarzystwo Teologiczne.

Kochel, J. (2002). W szkole Słowa Bożego. Medytacje w rytmie lectio divina. Redakcja

Wydawnictw Wydziału Teologicznego Uniwersytetu Opolskiego.

Kodeks prawa kanonicznego. Przekład polski zatwierdzony przez Konferencje Episkopatu. (1984). Pallottinum.

Kongregacja ds. Duchowieństwa. (2002). Kapłan, pasterz i przewodnik wspólnoty parafialnej. Kongregacja Kultu Bożego i Dyscypliny Sakramentów. (2004). Redemptionis sacramentum. Kongregacja Kultu Bożego i Dyscypliny Sakramentów. (2015). Dyrektorium homiletyczne. Kosmowski, W. (1997). Komentator liturgiczny i jego posługa. Szkoła Animatora „AGAPE” Ruch Światło-Życie Diecezji Bydgoskiej. 
Krakowiak, C. (2005). Posługi i funkcje świeckich w liturgii w świetle nowego Ogólnego Wprowadzenia do Mszału Rzymskiego i instrukcji Redemptionis sacramentum. In W. Kazimieruk \& I. Chłopkowska (Eds.), Liturgia i ewangelizacja. Materiały z pierwszego sympozjum liturgicznego diecezji siedleckiej, Siedlce, 16 października 2004 r. (pp. 21-48). Wydawnictwo Sióstr Loretanek.

Kudasiewicz, J. (2000). Modlitwa Biblia. Wprowadzenie w lectio divina. Jedność.

Masini, M. (2001). Wrowadzenie do „lectio divina”. Teologia, metoda, duchowość, praktyka (B. Żurowska, Trans.). Bratni Zew.

Nadolski, B. (2006). Leksykon liturgii. Pallottinum.

Ogólne wprowadzenie do Mszału rzymskiego. Z trzeciego wydania Mszału Rzymskiego. Rzym 2002. (2004). Pallottinum.

Paciorek, A. (2000). Kerygmat. In Encyklopedia katolicka (Vol. 8, p. 1361). Towarzystwo Naukowe Katolickiego Uniwersytetu Lubelskiego.

Pius XI. (1931). Non abbiamo bisogno.

Przygoda, W. (2006). Apostolstwo świeckich. In R. Kamiński, W. Przygoda, \& M. Fiałkowski

(Eds.), Leksykon teologii pastoralnej (pp. 70-76). Towarzystwo Naukowe KUL.

Rahner, K., \& Vorgrimler, H. (1987). Mały słownik teologiczny (T. Mieszkowski \& P. Pachciarek, Trans.). Pax.

Secondin, B. (2006a). Modlitewna lektura Pisma Świętego: Vol. 1: Zasady, przykłady i metoda lectio divina w grupie i dla osób indywidualnych (A. Ryndak-Laciuga, Trans.). Wydawnictwo Bratni Zew.

Secondin, B. (2006b). Modlitewna lektura Pisma Świętego: Vol. 2: 27 przykładów, aby nauczyć się medytacji lectio divina (A. Ryndak-Laciuga, Trans.). Wydawnictwo Bratni Zew.

Sobór Watykański II. (1963). Sacrosanctum Concilium.

Starowieyski, M. (Ed.). (2014). Karmię was tym, czym sam żyję. Ojcowie Kościoła komentuja niedzielne czytania biblijne. Rok B (4th ed.). Wydawnictwo WAM Księża Jezuici.

Starowieyski, M. (Ed.). (2015). Karmię was tym, czym sam żyję. Ojcowie Kościoła komentuja niedzielne czytania biblijne. Rok C (2nd ed.). Wydawnictwo WAM Księża Jezuici.

Stypułkowska, B. (2015). Biblijna formacja katechetów. Wydawnictwo Naukowe Wyższego Instytutu Teologicznego.

Stypułkowska, B. (2020). Przygotowanie dorosłych do posługi lektora w ramach katechezy biblijnej. In R. Ceglarek \& P. Maciaszek (Eds.), Teologiczne refleksje wokół tajemnicy wiary (pp. 105-116). Częstochowskie Wydawnictwo Archidiecezjalnej Regina Poloniae.

Świerzawski, W. (1983). Eucharystia Chrystusa i Kościoła. Wydawnictwo Apostolstwa Modlitwy.

Witczyk, H., \& Haręzga, S. (Eds.). (2004). Uważajcie, jak słuchacie (Łk 8, 18). Teoria i praktyka lectio divina. Instytut Teologii Biblijnej Verbum. 
Wojdecki, W., Garrone, G. M., \& Starowieyski, M. (Eds.). (2013). Karmię Was tym, czym sam żyję. Ojcowie Kościoła komentują niedzielne czytania biblijne. Rok A (2nd ed.). Wydawnictwo WAM Księża Jezuici.

Wons, K. (2000). Jak żyć stowem Bożym na co dzień? Wydawnictwo Salwator.

Wprowadzenie do drugiego wydania Lekcjonarza mszalnego z 1981 roku. (2015). In Lekcjonarz mszalny: Vol. 1: Okres Adwentu, okres Narodzenia Pańskiego (2nd ed., pp. 11-55). Wydawnictwo Pallottinum.

Zatorski, W. (1999). Ustyszeć stowo Boże. Praktyka „lectio divina”. Tyniec - Wydawnictwo Benedyktynów. 